Homenagem

\title{
Maria Lúcia de Barros Mott: pesquisadora millitante
}

Após notificarmos recentemente os falecimentos de Heleieth Saffioti (REF, v. 18, n. 3) e Karin Smigay (REF, v. 19, n. 1), temos novamente esse dever sofrido de noticiar uma grande perda, agora de Maria Lúcia de Barros Mott, falecida em 26 de junho de 201 1, em São Paulo, onde nasceu.

Vivenciando recentemente a perda de familiares de amigas e a perda de amigas queridas, temos ficado abaladas com a necessidade que se tem repetido de elaborar essas notas de falecimento nos últimos números da revista. Estamos perdendo também nossas amigas/companheiras feministas e, por mais que saibamos que a morte faz parte e é consequência natural da vida, estamos conscientes também de que sua elaboração no luto é um trabalho, como definiu Freud, um trabalho individual penoso e com tempo próprio. Na REF a perda de Maria Lúcia Mott foi sofrida de forma coletiva.

$\mathrm{Eu}$, que não a conheci pessoalmente, retomei os relatos que ela fez de sua trajetória, em entrevista concedida a Joana Pedro em 2005, em Florianópolis. Relato que me causou muita comoção e com o qual me senti de certa forma identificada, pois, malgrado eu ter nascido no início da década e ela já na parte final dos anos 40 , pertencemos a uma mesma geração, com experiências em comum. Ela se retratou por inteiro nesse depoimento, em que falou de sua trajetória acadêmica, seu interesse em cultura popular e nos cultos afro-brasileiros, suas atividades artísticas, suas viagens. Maria Lúcia relata que iniciou o curso de História na USP em 1968, sem saber muito bem o que queria ser/fazer. Fala de seu envolvimento com os artistas que expunham na Praça da República, ela que fazia cerâmica, pintava quadros, identificada com a geração hippie e a ideologia da contracultura.

Contou sobre sua origem, sua vinda de uma família extensa, católica, com irmãos que a influenciaram nos ideais de esquerda. As indefinições da juventude a levaram a suspender os estudos de graduação para viajar, morando na França por mais de um ano, nos Estados Unidos, por quase um ano, países em que procurou fazer cursos sobre cultura negra. Retornou ao Brasil, foi para a Inglaterra e depois para a Índia, andanças que qualificou como relacionadas às inquietudes de sua geração: "Essa busca por alguma coisa..". Seu curso de graduação foi, assim, realizado em período longo, entremeado por suas viagens.

Em 1976, quando voltou ao Brasil, foi trabalhar na Fundação Carlos Chagas (FCC) e aí se deparou com o que chamou de "Escola da vida, fantástica". Encontrou-se como 
feminista e como pesquisadora. "Sempre via a pesquisa como uma forma de militância política."

Nessa perspectiva de militância feminista, Maria Lúcia relata na entrevista sua participação no jornal Mulherio: "participei com matéria acho que desde o começo (...) na edição mesmo, foi no período final que participei (...) fazia matéria, fazia revisão, fazia basicamente tudo, só não vendia, mas o resto fazia meio que tudo (...)".

À pergunta de Joana "Militas pela pesquisa?", ela responde: "eu acho que você ser comprometida com uma pesquisa crítica, que você trará contribuição, eu acho que essa é a coisa mais importante, de fato, da minha vida (...) A pesquisa, essa contribuição crítica que eventualmente você vai deixar".

Coerente com isso, consta de seu curriculum Lattes:

Maria Lucia Mott é historiadora e desenvolve pesquisas em história da saúde desde os anos 1980, começando com estudos de gênero ainda no início do desenvolvimento da área de pesquisa no Brasil. Atualmente é pesquisadora do Instituto Butantan (Secretaria de Estado da Saúde de São Paulo). Tem coordenado pesquisas, publicado trabalhos, realizado conferências e participado de eventos ligados a História das Políticas, Instituições e Profissionais de Saúde; Filantropia; Gênero; Memória e História da Saúde.

Com relação à Revista Estudos Feministas, Maria Lúcia participou do Comitê Editorial da REF em sua fase inicial no Rio de Janeiro, desde o número zero, de 1992, por todo o período em que foi editada pelo CIEC/ECO/UFRJ (até o final de 1994).

Além de ter trabalhado na avaliação de muitos artigos como parecerista ad hoc da revista por todos esses anos, Maria Lúcia publicou artigos no volume 2, n. 2/1994 ("Mme. Durocher, modista e parteira") e no volume 7, n. 1 e 2/1999 ("A parte ignorante: um erro de diagnóstico médico?"). Tendo publicado também resenha na revista (n. 2/1994), em 2002 (volume 10, n. 2) foi responsável pela organização do Dossiê "Parto", que traz seu artigo "Bibliografia comentada sobre a assistência ao parto no Brasil (1972-2002)".

A respeito dos percursos de Maria Lúcia relacionados à sua pesquisa militante sobre parto, a fala a seguir, de Susi, que conviveu com ela, pode nos dizer bem mais.

Mara Coelho de Souza Lago Universidade Federal de Santa Catarina

Minha entrada no tema da assistência ao parto se deu pelo olhar e pela perspectiva de Maria Lúcia Mott, a quem conhecei "em carne e osso" em um congresso da ANPUH em $\mathrm{BH}$, no final do século passado, e de quem já conhecia o maravilhoso texto "Mme. Durocher, modista e parteira". Logo após, entrei em contato com o texto "Um erro de diagnóstico médico", outro trabalho que considero imprescindível para todos e todas que se interessam pelo campo médico e suas relações tensas e controversas com os saberes populares. Esta perspectiva, refinada e detalhista, sem deixar de ser feminista, está presente em tantos outros trabalhos de Maria Lúcia, os quais sempre me chamaram atenção pelo estilo literário. Acredito ser digno de destaque o seu cuidado em textos primorosos, baseados sempre em farta e minuciosa pesquisa historiográfica, apresentados em nossos congressos acadêmicos e feministas, nos quais tive o prazer de compartilhar vários momentos deste "saber-fazer feminista", incluindo a participação no Dossiê Parto, de 2002, que ela organizou com seu tradicional zelo e cuidado. 
Numa destas ocasiões, descobri que as viagens pelos mundos da assistência ao parto a tinham feito recriar, poeticamente, a vida das Mme. Durocher (mãe e filha), no livro intitulado O romance de Ana Durocher, que obtive através de Joana Pedro, já que se achava esgotado na época. Depois disto, acompanhei seus trabalhos sobre maternalismo e benemerência, dos quais destaco aquele publicado nos Cadernos Pagu em 2001. Além da notável dedicação e seriedade nas pesquisas que fazia, Maria Lúcia, que chamávamos carinhosamente de Cuca, sempre se fez acompanhar de grande gentileza e humildade, atributos que hoje têm escasseado no mundo universitário, no qual pressa e arrogância parecem sempre ser os principais convidados. Cuca deixa trabalhos fundamentais nos estudos de gênero, neste campo espinhoso e tenso que são as reflexões e pesquisas sobre maternidade e feminismo, tanto para nós, situadas neste campo, como para nossas/os colegas dos campos da saúde coletiva, enfermagem e medicina. Ganhei de Maria Lúcia, junto com o livro $O$ gesto que salva, sobre Pérola Byington, um lindo colar de pecinhas azuis, confeccionado por ela, lembrança afetuosa que guardo junto com seus textos e minha memória.

Carmen Susana Tornquist Universidade do Estado de Santa Catarina 